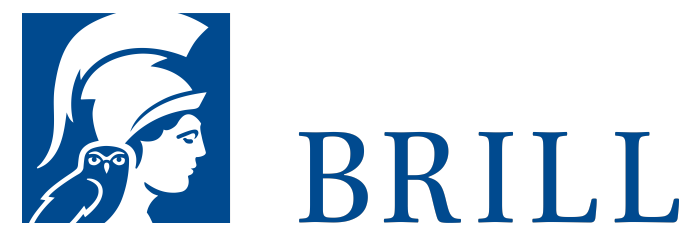

\title{
Moralische Intuition und ethische Rechtfertigung
}

Eine Untersuchung zum ethischen Intuitionismus

Author: Bert Heinrichs

Lange Zeit war der Verweis auf intuitiv erfassbare Prinzipien das vorherrschende Begründungsverfahren in der Moralphilosophie. Während der sogenannte „ethische Intuitionismus“ noch zu Beginn des 20. Jahrhunderts zumindest in der britischen Moralphilosophie die dominante Strömung darstellte, galt er seit der Mitte des Jahrhunderts aufgrund vielfältiger Probleme als nicht mehr theoriefähig und geriet nahezu in Vergessenheit. In den vergangenen zehn Jahren ist ein gewisses Revival des ethischen Intuitionismus zu beobachten, nicht zuletzt im Kontext der angewandten Ethik. Vor diesem Hintergrund bietet das vorliegende Buch eine umfassende Analyse des ethischen Intuitionismus. Dazu werden frühe Ansätze aus dem 17. und 18. Jahrhundert wie auch die klassischen Positionen aus dem späten 19. und frühen 20. Jahrhundert ausführlich rekonstruiert. Auf dieser historisch informierten Grundlage werden zeitgenössische Ansätze zur Fortentwicklung des ethischen Intuitionismus kritisch diskutiert. Schließlich wird mit einer an Kant anknüpfenden Ethik der Person ein systematischer Vorschlag unterbreitet, der sich als Variante des ethischen Intuitionismus verstehen lässt und der unmittelbar auf aktuelle Diskussionen in der Metaethik bezogen ist.

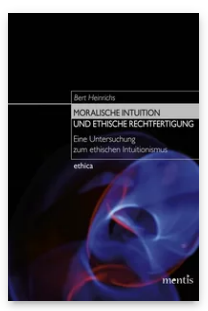

Pages: 316

Seiten

Language:

German

Subjects:

General,

Philosophy

Publisher: Brill | mentis

Series:

ethica, Volume:

28

E-Book (PDF)

Released online:

o1 Jan 2014

ISBN: 978-3-

89785-870-1

List price

Paperback

Publication date:

o1 Jan 2014

ISBN: 978-3-

89785-325-6

List price 
For more information see brill.com

Order information: Order online at brill.com +44330 333 0049 | customerservices@brill.com Submission information: brill.com/authors

Titles published by Brill | Fink, Brill | mentis or Brill | Schöningh: +49(o)715413279216| brill@brocom.de 